Oscar A. Braunbeck; Paulo Sérgio Graziano Magalhães. "TECHNOLOGICAL EVALUATION OF SUGARCANE MECHANIZATION", p.451-464. In Luis Augusto Barbosa Cortez (Coord.). Sugarcane bioethanol - R\&D for Productivity and Sustainability, São Paulo: Editora Edgard Blücher, 2014. http://dx.doi.org/10.5151/BlucherOA-Sugarcane-SUGARCANEBIOETHANOL_42

\title{
TECHNOLOGICAL EVALUATION OF SUGARCANE MECHANIZATION
}

\section{Oscar A. Braunbeck and Paulo Sérgio Graziano Magalhães}

The expectations of expansion of the cultivated area with sugarcane, from 7 million hectares in 2008 up to 14 million hectares in 2030, will demand significant alterations in the whole mechanization system, in order to place the activity in less vulnerable levels of sustainability. The sugarcane is a semi perennial crop typically grown in cycles of four-seven years, producing on average 81 ton/ ha-1-year (CONAB, 2008). About 1.4 million hectares are replanted every year, and in only $30 \%$ of them mechanical planters are used, in the remaining of the area planting is semi mechanized. The method is totally manual and restricted to areas of little significance with high steepness, predominantly in the northeast part of Brazil. Sugarcane is usually planted in the rainy period, between January and March, to be harvested in the following crop season, causing a productive system deficit of one year. During the period between the harvest of the last cycle and the planting of the new one, some mills do crop rotation with legume species. Cane harvesting use to be traditionally done manually, but it has witnessed a rapid transformation in the last decade due to mechanical harvesting, , mainly as a response to environmental legislation that restricts the use of field burning.

The increase of ethanol production certainly passes through changes in both: the agricultural and the industrial process so as to make possible the integral use of the sugarcane produced. According to Dourado Neto (2007) the current production model needs to be reformulated to increase productivity, from an economic, social and environmental sustainability point of view; it is necessary to define agriculture strategies for a better use of resources. The technology of agricultural production should be improved with focus not only in yield and the reduction in demand for new areas, but mainly to improve environmental impacts for which mechanization has significant contribution to make.

\section{MECHANIZATION}

Considering mechanization as equipment that replaces or aids manual and animal work, it can be said that it is necessary in most phases of sugarcane production cycle to provide competitive and sustainable conditions for plant growth e.g. erradication of the stooll, physical and chemical conditioning of the seedbed, soil moisture control, planting and agrochemical applications all the way up to cane harvesting and delivery. Mechanization is particularly important in harvesting and transport operations from the field to the mill, as a consequence of the high amount of biomass that needs to be handled.

Currently grains production is the most highly mechanised. The grains dominate the equipments market in function of its production area far higher than for sugarcane, as illustrated in Table 1. The model of grains mechanization, with more than a century of evolution, was extended to sugarcane although its characteristics are different, mainly because it is a semi perennial crop, with a volume of annual biomass much higher than grains. For example, Table 1 shows that the globally planted and harvested area with cereals is close to 32 times 
TABLE 1 Production and world productivity of grain and sugarcane

\begin{tabular}{|l|c|c|}
\hline \multicolumn{1}{|c|}{ Product } & $\begin{array}{c}\text { Harvested area } \\
\text { (ha x 10 } \text { 10 }^{\mathbf{6}}\end{array}$ & $\begin{array}{c}\text { Productivity } \\
\left(\mathbf{t} . \text { ha }^{-1} \text { ) }\right.\end{array}$ \\
\hline Sugarcane & 21.9 & 70.8 \\
\hline Cereals & 700 & 3.3 \\
\hline Soy bean & 94.9 & 2.3 \\
\hline Wheat & 217.4 & 2.8 \\
\hline
\end{tabular}

Source: FAO - Faostat (2008).

higher than sugarcane area; this justifies why the mechanization profile is defined by the cereal sector. The table also shows mass volume per hectare harvested annually is about 21 times higher in the case of the sugarcane. Considering the annual cycle for cereals and for sugarcane, the amount of mass removed by hectare between two consecutives seedbed preparations is 105 times superior in the case of sugarcane. The process of biomass removal is associated with intense machinery movements (all kind of equipment) with different wheel track mismatching crop row spacing, which varies between 1 and $1.5 \mathrm{~m}$; the result of this poor combination of equipment wheel track is a high percentage of area being trafficked.

There are some characteristics of the current mechanization system that damages the stalks, the soil and increase the operational costs and therefore requires new research to find ways to reduce their effects.

Tractors, harvesters and wagon have not standardized narrow track width, it frequently mismatching the crop row spacing practiced in sugarcane. The outcome is traffic passing too close to crop rows, and sometimes directly running over them, damaging the stalks. These equipments do not allow taking advantage of the controlled traffic technique.

Harvesters are primarily designed for single row and pass twice for each inter-row with the side wagon. The harvested cane is transported inside the field by wagons pulled by tractors where the traction capacity depends on the tractor own weight rather than on the transported load. The system uses approximately $50 \mathrm{t}$ of equipments to remove $80 \mathrm{t}$ of biomass per hectare.

The most widespread configuration is a tractor with two wagons characterized for being a long composition that demands space for maneuver, usually quite superior to the available at the in field roads.

The agricultural tractor and sugarcane harvesters define or influence row spacing, the area geometric lay out, the pattern of traffic in the field as well as the size and the design of most of implement. The problems posed by mechanization are not unique to Brazil; the world sugar industry suffers a great mismatching of row spacing and equipments track width, according to Cox (2006). Equipment movements and soil compaction are much more severe for sugarcane than for cereals. It seems valid, from an economical and environmental point of view, to consider specific mechanization solutions for sugarcane, focus in solving this specific problem.

The conventional mechanization of sugarcane in Brazil has gone through an improvement process from 1975 to 2005, based in operation standardization, adaptation of the tractors power to demand, with larger work capacity, maintenance programming and control, operator training, incorporation of new equipments for planting, application of filter cake and stalks elimination, among others. That evolution contributed to reduce production costs, which is the lowest worldwide. It can be affirmed that the principal responsible for that evolution were the technicians in the cane mills, with the support of regional manufacturers and research institutions that shared the common objective of reducing costs and simplicity and quality of operations.

That evolution seems to have reached a plateau with very little gains, since conceptual bottlenecks of conventional mechanization have been reached e.g. excessive traffic, low quality of the raw material, harvesting losses, heterogeneous billet distribution in the planting furrow, as well as the low quality and the high cost of the trash recovered.

The technological evolution of the mechanization in order to turn sugarcane production more 
sustainable within the next 30 years, could be much more effective if restrictions imposed by tractors and harvesters could be eliminated. Such improvement will allow to create new opportunities, and open the door to many technicians, users and suppliers of farm equipment with extensive experience in sugarcane.

A brief analysis of the historical and the basic functions and physical principles involved in the design of tractors, can contribute to the formulation of proposals which can reduce the negative impacts of t mechanization, as it is the case of the controlled traffic concept.

The agricultural tractor concept has not changed since its introduction at the end of the XIX century. Analyzing the three generations of tractors presented in Figure 1 it can be observed that there was a technological evolution within of the same concept based in a power unit, steam or internal combustion engines, surrounded by four wheels, with narrows track width, less than $2 \mathrm{~m}$, with traction capacity generated through its own weight, with no transportation capacity and with implements coupled at the rear hindering the operator monitoring and control. In reality the concept suffers little changes from the previous stage that is the animal traction.

The tractor concept, as its name indicates, has its origin in the need of generating forces for implementing traction used in the intense soil tillage. That pulling force is generated based in the tractor own weight, through over dimensioned iron structures, iron ballasts added to the back and front wheels as well as water inside the trac- tion wheels. The agricultural tractor is part of the agricultural mechanization profile that requires investments and energy to act in a vicious circle of soil compaction and loosening with negative consequences on sustainability.

The mechanical concept of soil physical conditioning through intense and deep tillage is being substituted by the concept of minimum or zero tillage where the biological activity, the incorporation of organic matter from crop residues mulch, crop rotation, the permanence of roots from previous cycles and traffic reduction are capable to maintain adequate the soil condition for the development of a new crop. This system promotes drastic reductions in soil erosion, mechanization costs and water losses. It is also much more aligned with the emphatic demand of environmental preservation.

In conventional mechanization, the inputs and harvested products are frequently transported by wagons pulled by tractors. The wheel paths of those equipments usually follow the planting rows, but they are not selective in terms of concentrating the traffic in specific rows. The wagons, vehicles and tractors track width are not standardized to the point of allowing concentration of the traffic on specific lines.

Besides the fact that the tractor conception remained static, its technological evolution has been slowing down over time. In the period of 50 years between 1880 and 1930 an important technological evolution appeared with the substitution of the steam engine by the internal combustion engine with the Otto cycle. The next period of 20 years, between 1930 and 1950, the Otto cycle
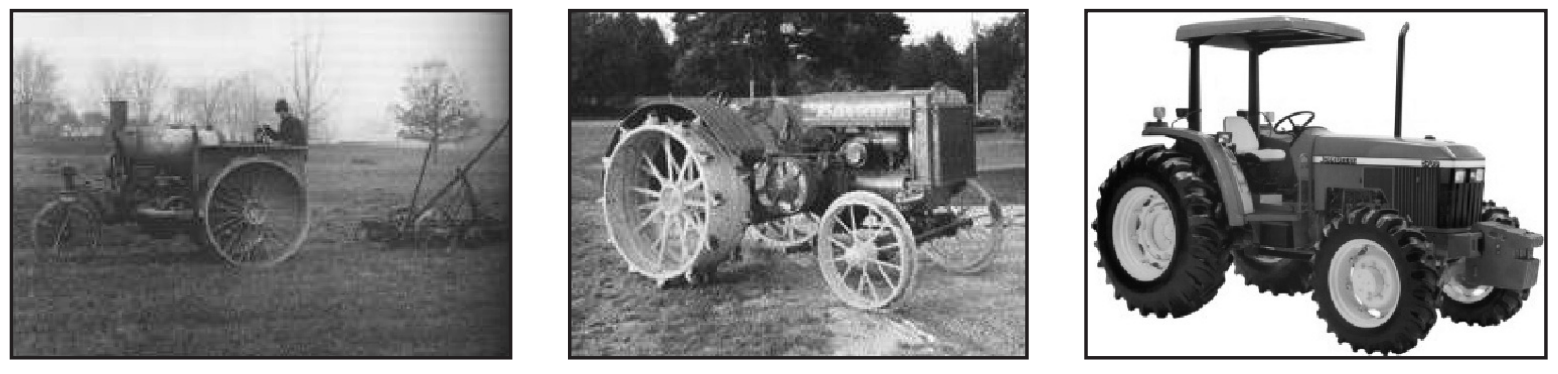

FIGURE 1 Evolution of the agricultural tractor over 130 years. 
engine was substituted by the diesel cycle engine and the steel wheels by pneumatic tires. The following years, until present, the evolution has been in terms of power increase and components such as hydraulic transmissions and electronic controls, but conserving the original concept of narrow track width, own weigh for traction generation, inadequate positioning of the implements and lack of load capacity.

The production cycle of sugarcane involves operations that demand energy for deep soil tillage, seedbed preparation, seed billets and fertilizers transport as well as harvesting and removal of approximately $100 \mathrm{t} / \mathrm{ha}^{-1}$ of biomass, including the trash. In that cycle, seedbed preparation is meant to create favorable atmosphere for the development of the plant allowing the infiltration and storage of water, the circulation of gases and the propagation of the roots, within fragile structure. However the wheels or crawler tracks of the equipments promote a re-accommodation of the particles creating a strong structural arrangement required to support the weight of the equipments. The tractors and the harvesters apply good part of their power source and fuel consumption to promote soil compaction.

Plants and wheels need to withstand different soil conditions. That conflict has been promoting research in the last decades to reduce soil pressure. Large tyres, with radial structure have been developed, to generate larger contact area and reduced soil pressure; in parallel to the weight of equipments such as transport vehicles, harvesters and tractors has been increased. The consequence is that the benefits of the introduction of high flotation tyres have been total or partially eliminated by the increase of the equipment weight. The effect of the tyres on the soil compaction, in terms of resistance to penetration, varies with soil type and moisture content. It can be observed in Figure 2, that there is some compaction reduction with the use of radial tyres, however the compaction provoked by both types of tyres, radial and diagonal, is superior to the of the soil without traffic.

On the other hand, the narrow track width of the tractors and harvesters together with the wider tyres increases the percentage of the soil surface trafficked. This percentage overcomes 50\%, in

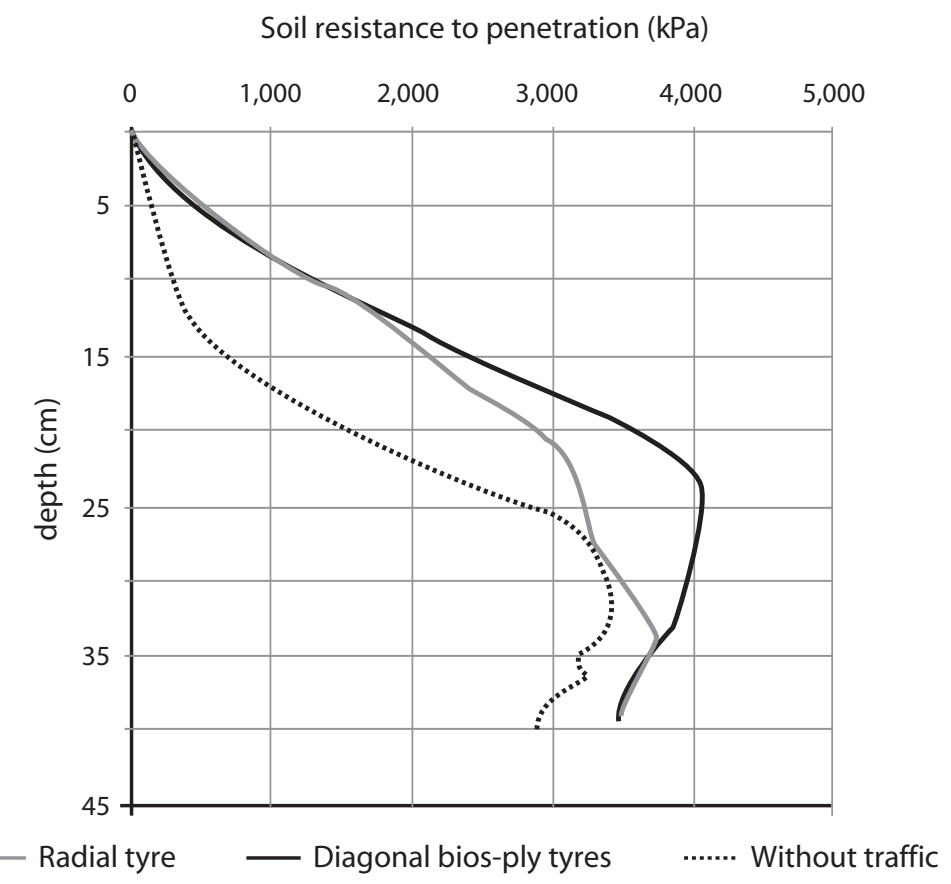

FIGURE 2 Soil resistance to penetration when submitted to different traffic conditions. 
the case of sugarcane. Everything indicates that new developments focused on reduction of soil compaction should be directed more to increase the track width of the equipments than to the increase of tire width.

The impact of the traffic on the soil and the plant is recognized by several authors e.g. Grange et al. (2004), Garside et al. (2005), Mari et al. (2006), Mari and Changying (2008), Mc Phee (1995), Naseri (2007) and Chamen et al. (1994). Today there is still potential to reduce those impacts using alternative mechanization that reduces the percentage of machinery movements in relation to the planted area. The noxious effect of the traffic on the soil structure is evident when the soil is well structured, in favorable conditions for the development of the crop and with good resistance to hydro erosion. If the soil is more compacted and dry the effect of the tyres becomes less perceptible, the development of the crop is difficult and there is a potential for soil erosion. Even if the effects of the traffic are less significant in the winter when the soil is dry, they are much more severe at the beginning and ending of the harvesting season when precipitations are more intense.

Considering the problems described between the wheel and the crop, it seems appropriate to separate the space dedicated to the development of the plant from the space dedicated to the traffic of wheels or crawlers which will reduce the impacts on the soil, Braunack and Garry (2006). This separation allows to improve both spaces and maximum development of the plant and maximum traction efficiency for the wheel. São Martinho mill, in Pradópolis region, has been practicing this philosophy using modified conventional equipments, with good results in terms of yield recovery. In the past the reduced yield was consequence of the intense and uncontrolled movements of harvesters and wagons; even using narrow track width harvesters $(1.6 \mathrm{~m})$ and $3 \mathrm{~m}$ for the tractors and wagons such dimensions allow to maintain a $0.7 \mathrm{~m}$ strip dedicated exclusively to the plant and a $0.8 \mathrm{~m}$ strip dedicated exclusively to the wheels.

Manor (1995) analyzes alternative mechanization based on controlled traffic of elevated, selfpropelled wide frame structures, to execute all the operations of the agricultural cycle with drastic reduction in the soil trafficked areas. It presents a potential for costs reduction and productivity increase. The author highlights other potential advantages of these equipments such as the agro chemical pulverization in closed cameras with reduction of drift, and the possibility of transporting the harvested product in the wide frame, thus avoiding the traffic of container wagons in the area.

The demand that encouraged the development of conventional mechanization dates back to the end of the XIX century. This mechanization model improved during the XX century, focusing primarily on costs reduction through the use of higher power required by the heavy soil tillage operations as well as seedbed preparation and harvesting, for which animal power was insufficient. It was also concerned to replace the scarce labor as a result of migration to the urban centers. It is observed that demand changed in the present century with relationship to the soil tillage and seedbed preparation where sustainability demands are added. That can be materialized through changes in the agricultural practices, as it is the case of the controlled traffic, the zero tillage and precision agriculture.

Considering that conservative agriculture (CA) technologies are being tested in approximately 88 million hectares all over the world, and has seen an increment of more than 50 times in South America in the last 20 years alone, it is questionable why the Brazilian sugarcane industry does not use this technology as a strategy to reduce costs, to conserve the soil and the water, and improve sustainability of agricultural production. The potential advantages of the zero-tillage, in the case of the sugarcane, do not differ much from other crops in which the result has been well demonstrated.

The sugarcane industry can also benefit from mechanization technologies that promote the reduction of investment, operational costs, reduce harvesting losses, and reduce fossil fuels use and their emissions, and the optmize operational efficiency of the complex cycles of mechanized operations involving several interacting equipments.

The evolution of agronomic technologies emphasizes the need for mechanization more adapted 
to agronomic conditions, without imposing limitations to evolution as it is the case of that limits the planting row space of sugarcane equipments track width.

In the last decade environmental legislation has been forcing to reduce sugarcane burning to minimum levels, forcing an increase of mechanical green harvesting that leaves on the soil about 15 t.ha ${ }^{-1}$ of trash (d.b.), forming a mulch 100 to 200 mm thick. Cane planting can be done directly over this mulch, and it is done by some mills, or the remaining straw of other crops used in the rotation cycle. The mulch covering conditions of the soil for implantation of the zero-tillage in sugarcane are favorable.

The technique of controlled traffic (CT) has demonstrated to be a successful innovation in Australia. Figure 3 shows the evolution of the areas in CT, in that country. According to Yule and Radford (2003) the controlled traffic leads to productivity earnings, reduction of operational costs and of investments; and reduces runoff and erosion, increases steady infiltration rate, as well as improvement in the soil physical condition and fertility.

Controlled traffic maintains compacted tracks permanently, avoiding the cost associated to the vicious cycle of soil compaction and loosening practiced in conventional planting system. When controlled traffic is applied to sugarcane, using conventional mechanization, strips approximately $0.8 \mathrm{~m}$ wide, spaced of $1.5 \mathrm{~m}$, are traffic dedicated. It means that close to $50 \%$ of the area is used by tires or crawlers of the harvester, tractors and self tipping wagons. The narrow track of the tractors and harvester promotes the traffic condition as illustrated in Figure 4 where each small rectangle represents the passage of two wheels. Wheel traffic is much higher on the top eight lines of the figure that corresponds to the harvesting operation including harvester, tractor and self tipping wagons. The illustration considers mechanized operations involved in an 18 month cycle of sugarcane. It can be observed that 32 tires pass in some inter-rows suggesting that some alternative mechanization system would be required to be able to move into no tillage farming.

Braunack and Garry (2006) compared the effects of controlled and random traffic as well as the effect of conventional intensive soil cultivation and reduced tillage on seedbed and crop growth as well as the effect on soil physical parameters and soil macro-fauna. The results indicated that the controlled traffic and reduced tillage would benefit the crop system minimizing soil degradation and maintaining productivity in a sustainable manner.

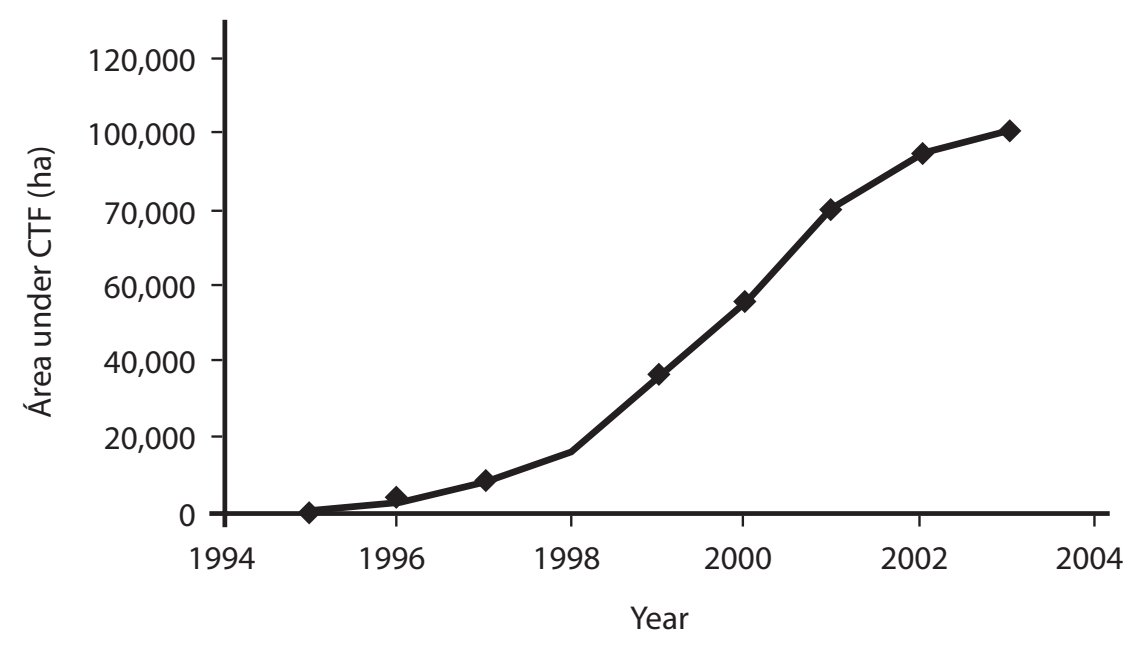

Source: YULE (2003).

FIGURE 3 Evolution o controlled traffic in Australia. 


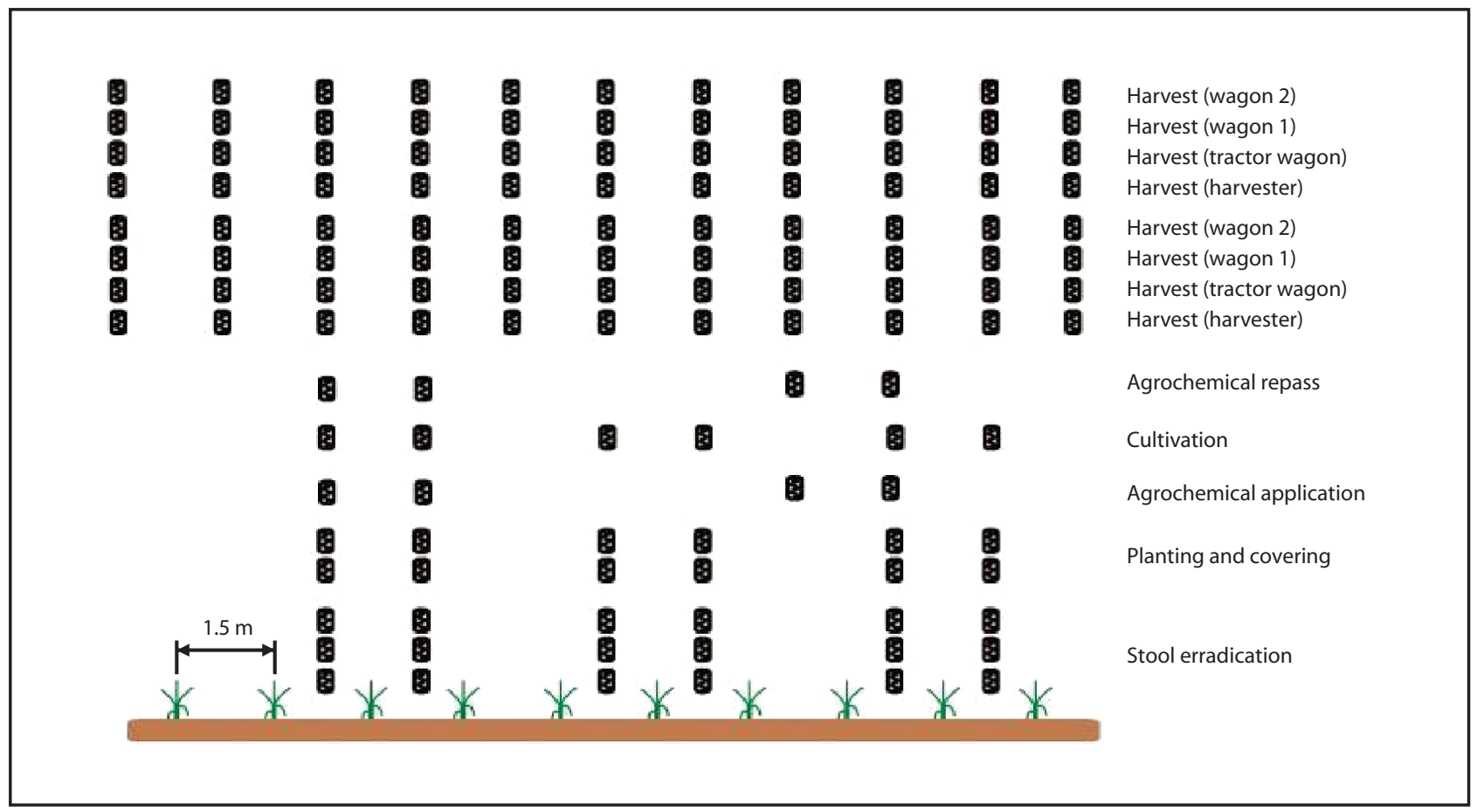

FIGURE 4 Number of double tire passes at plant cane inter-rows during an 18 month cycle.

The alternative equipment described by Manor (1995) apply the concept of controlled traffic, can contribute to break the paradigm of conventional mechanization progressively and open a new range of development opportunities for research and production sector. As the number of simultaneous rows harvested is increased the percentage of trafficked area is proportionally reduced.

\section{SEEDBED PREPARATION}

Land preparation for planting sugarcane takes place at four to six years intervals, or even up to ten years, depending on several factors such as soil type, irrigation or fertigation, climatic conditions and type of cultivation, or cultivation techniques applied in the previous years. Soil tillage can follow different approaches, often includes one or two heavy passes of offset disc harrow to eliminate the previous stool, or it can be done chemically by spraying glyphosate over the emerging ratoon. Due to the intense traffic of machines during the crop cycle, subsoiling operations are required as well as additional harrowing or ploughing operation, followed by disk leveling operation with the objective of reducing the size of soil aggregates. Detected the need of limestone application for base saturation elevation up to $60 \%$, this should be done, as uniform as possible, in the period between the beginning of soil tillage and before the last harrowing.

According to Ide (2007) little research is being conducted on soil tillage for sugarcane and many reports do not present scientific background on the dynamics of soil biotypes, physicochemical modifications as well as water and nutrient dynamics, mainly in green cane plantations. There are bottlenecks in relatioon to the effectiveness of implements used for tillage and the efficient and correct methods to conduct this operation. The author concludes that the main challenges in this process are: 1 - to evaluate the environmental impacts of the current tillage process; 2 - develop smaller and more versatile equipments for liming and herbicide applications.

According to Braunbeck (2008) a conservative agriculture, such as zero tillage, is a promising route to mitigate the negative effects of conventional tillage on water and soil conservation in the sugarcane industry. Direct seedling is a planting 
method without soil tillage. Just a narrow strip of soil is tilled in the row where the seeds or billets are deposited, maintaining crop residues on the soil surface. In early 1960's, this technique was first used in England, in an experimental way, and later improved in the United States, where around 23 million hectares using this method are cultivated today. In Brazil, the system of direct seedling began to be implanted at the beginning of the seventies, in the north of the state of Paraná, with the objective of reducing soil erosion. In the 1990 's, the system began to be used extensively in the state of Rio Grande do Sul and to a less extend in the "Cerrados" (GO, MG and DF). Currently the cultivated area with zero tillage in Brazil is over 25 million hectares.

Nowadays, in Brazil zero tillage is accepted as irreversible; it is used mainly in soya bean but is also to a large extend in corn, wheat and beans farming, which is increasing rapidly, Smiderle (2005).

Studies done by the Fundação Agrisus - Sustainable Agriculture, focused on the state of the art of zero-tillage, verified that in $77 \%$, or 22 Mha of soya beans, use zero-tillage, and approximately $65 \%$ of the framers have been using zero tillage for more than 10 years. The study considered four climatic areas with differentiated conditions in the winter (1 - cold and rainy - Rio Grande do Sul, Santa Catarina and south of Paraná, 2 - unpredictable rainfall - remaining of Paraná, south of Mato Gross do Sul and Southwest of São Paulo, 3 - warm with little rain - north of Mato Grosso do Sul, Mato Grosso, Rorâima, remaining of São Paulo, Southwest of Goiás, Minas Gerais triangle; 4 - hot and dry - remaining of Goiás, Tocantins, south of Pará, west of Bahia, southwest of Piauí and Maranhão). Cardoso (2006).

\section{Straw and Soil Protection}

Although the main motivation of the sugarcane growers to adopt zero-tillage is costs, soil conservation is equally important for environmental protection. Soil degradation can be considered as one of the most important environmental problems, as it is very harmful e.g. it has a direct impact on productivity, and causes silting up and pollution of water sources. The constant crop improvement, together with greater use of chemical fertilizers and more efficient pest control, tend to hide erosion impacts and thus little priority is given to its control.

The process of water erosion of the soil particles happens in three sequential phases: loosening, drag and deposition. In the initial phase the loosening of aggregated soil particles results from the impact of water drops and the action of superficial water run-off. In a second phase, the loosened particles can stay close to the aggregate or be transported be the running water. The straw mulch protects the soil in both phases of the erosive process, in the first phase the straw absorbs the kinetic energy of the rain drops and in the second phase it reduces the speed of the superficial run-off and it holds back the displacement of particles.

Silva (2005) used a rain simulator on red-yellow argisoil, with $9.5 \%$ slope to analyze the effect on of soil cover losses using four precipitation intensities $\left(60 ; 80 ; 100\right.$ and $\left.120 \mathrm{~mm} \cdot \mathrm{h}^{-1}\right)$ on different percentages of soil covering $(0 ; 20 ; 40 ; 60 ; 80$ and $100 \%)$. The effect of the soil covering percentage on the soil losses accumulated at the end of the six rain events, for the different precipitation intensities studied is shown in Figure 5. The authors verified that, independently of the precipitation intensity, the increment of the covering percentage caused accentuated reduction in the soil losses, becoming very small when covering approaches $100 \%$ of the soil surface.

The amount of available vegetable material for soil covering is critical in some cultures, mainly in areas with higher temperatures. In the case of the sugarcane there is a fraction of approximately one third of the biomass produced that can be used for soil protection. Burning the cane before harvesting limits the biomass available for soil protection, but with the intensification of the green cane harvesting there will be enough material for soil covering.

Conventional soil tillage promotes, in a mechanical way, vertical movement of nutrients with low mobility. In zero-tillage that movement can be obtained through crop rotation during plantation renewal. Tanimoto (2008) in experiments done in 


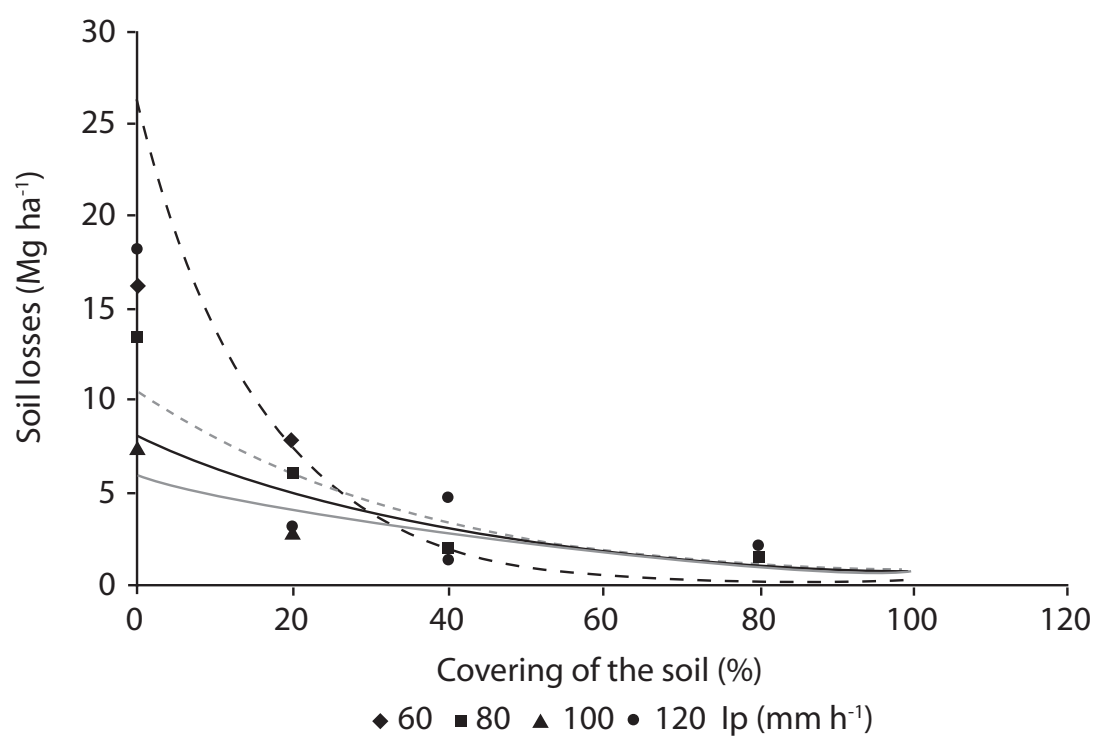

Source: SILVA (2005).

FIGURE 5 Soil losses as function of the percentage of covering of the soil and precipitation intensity.

north and northeast areas of the State of São Paulo verified that growing soya bean or crotalaria in the sugarcane trash, as crop rotation, makes possible the mechanical sugarcane planting after harvesting of the legume, with little movement of the soil. According to the author with relationship to the soil-borne diseases when they happen, their effects can be minimized, keeping the population of those pests at the acceptable level with crop rotation.

Soil protection obtained with surface trash has a secondary equally positive effect related to water retention. Water has significant effect on sugarcane productivity, because when restrained, reduces yield significantly even in fertile soils and, when appropriate, it increases the production even in the soils with less potential. Sustainable use of natural resources means reduced water run-off, and increased efficiency of water and nutrients use.

Soil covering with crop residues is a decisive factor in the process of water infiltration. Trash covering the soil increases water retention, since it reduces the evapotranspiration and reduces, or even eliminates the superficial run-off. Studies indicate a reduction in water loss of approximately $70 \%$ with the use of the zero-tillage, as shown in Figure 6, Domingues (2006).

\section{Trash Decomposition and Soil Fertility}

Similar to water, soil fertility also occupies a prominent place in sugarcane cultivation. The level of soil fertility, when involving biological, physical and chemical aspects, is determined basically by its structure. Besides the favourable effects of the presence of trash not decomposed on the soil surface, the material already decomposed is also beneficial. In the long run, trash decom-

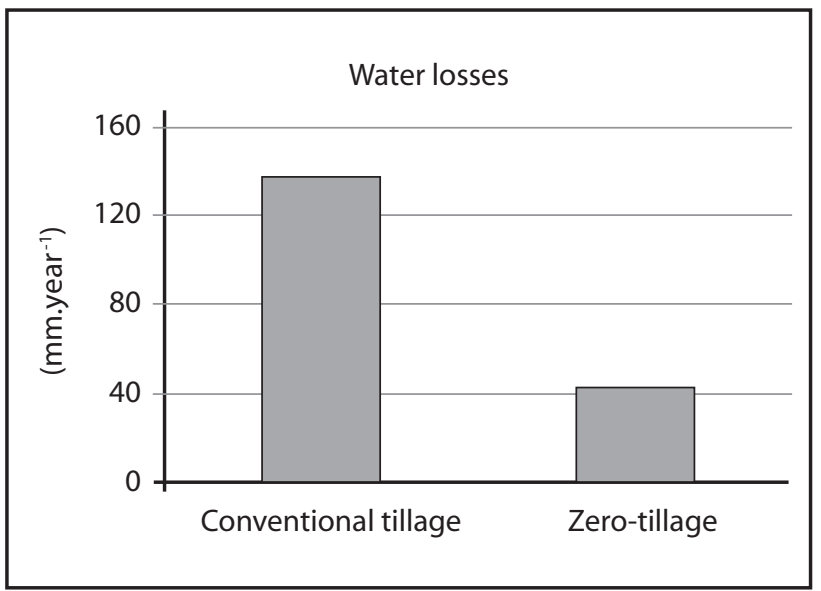

FIGURE 6 Water losses in conventional soil tillage and zero-tillage. 
position increases soil organic matter content, which has a conditioning effect on soil, because it aggregates the particles, improving its physical structure, what reduces or eliminates the need of harrowing or ploughing operations for soil physical conditioning.

One of the most significant effects of the increase of soil organic matter content, it is the increase in Cation Exchange Capacity (CEC). CEC is the capacity of a soil for ion exchange of cations between the soil and the soil solution. CEC is used as a measure of fertility, nutrient retention capacity, and the capacity to protect groundwater from cation contamination. Most of the Brazilian soils have low fertility and are poor in organic matter; one of the main forms of increasing nutrient storage capacity is by increasing the organic matter content. Studies done by Souza (2005) indicated yield increase when using trash on the soil surface, but mainly when trash was incorporated into the soil, however, the soil mobilization to homogenize crop and residues oxygenates the soil and stimulates the microorganisms decomposition effect that accelerate the rate of organic matter losses. Conventional tillage can duplicate the rate of organic matter mineralization in relation to zerotillage. The mineralization of the soil stable organic matter changes its structure and degrades fertility.

The increase of the organic matter content in the soil increases carbon stock, collaborating for greenhouse gas effect reduction. The potential of carbon sequestration, through zero-tillage, is also related to a reduction of fossil fuels use, to the erosion control, and to a reduced use of fertilizers.

Summarizing, the main advantages of zero tillage are the improvement of the soil structure; the increase of the biological activity; the increase of the organic matter content; the increase in crop yield; the reduction of the operational costs and investments in mechanization; time saving because there is a reduction in the number of operations; the fertilizer long run economy and a differentiated handling of the trash which results in more efficient energy use of sugarcane biomass.

The implantation of zero-tillage in sugarcane requires significant changes in cultivation method and corresponding investments in research and development to eliminate the problems associated to those changes. Some of the difficulties are: break the conventional tillage paradigm; the need to eliminate cane burning; weed control; the potential for increase in soil pests that are beneficiary of the non soil movement, as well as the need to fertilize and lime through the trash layer.

Considering the gains and challenges described and the successful experience of grains, zero-tillage can be considered an agricultural practice with great potential contribution to turn the sugarcane agriculture more sustainable, and it opens horizons for a new cycle for technological evolution of the mechanization, as it happened with the conventional mechanization in the last thirty years, since the beginning of the Proálcool program.

\section{PLANTING}

Sugarcane is traditionally planted through vegetative propagation. Billet planting is becoming common and each billet usually has from 2 to 3 buds. Cutting of the stems into billets is required in order to break of the effect of the apical dominance existent among the buds distributed along the stem. Newer buds, located closer to the top, sprout more quickly and they delay the development of inferior bud. According to Gheller (1995), mentioned by Jamini (2007), the division of the stems in billets of 3 buds is applied traditionally in Brazil and other countries. The billets are an energy storage for bud nutrition during its emergency and until the development of the root system.

Sugarcane planting involves four main stages. Billet harvesting, billet transport to the planting area, the furrow opening, billet distribution in the bottom of the furrow, fertilizer application and furrow reclose.

The planting process can be partially or totally mechanized. In the semi-mechanized system "seed cane" harvesting and distribution in the furrow is done manually, being the main advantage of the semi-mechanized system the good uniformity of seed spacing in the furrow; the loading, unloading, transport, covering and the spraying operations are done mechanically. In the mechanized 
system the planting operations are executed in two phases, in the first the seed cane are billet harvested mechanically and transport to the target field where they are loaded into the planters, and in the second phase all the remaining operations are executed in only one pass of the planter. The mechanical system has significant reduction of labor and operational costs, but it requires more seed to overcome the lower quality of the seed spacing in the furrow.

Chopping the stems into billets presents restrictions in both manual and machine cut, cost and labor availability in the first case and damage to the buds in the second case. In the semi-mechanized system 4 to 8 t.ha $^{-1}$ of seed cane are used, depending on the variety, the planting period, as well as the soil and climatic conditions of the area. Mechanical planting requires almost 50\% more seed cane, from 8 to 12 t.ha-1, Janini (2008).

The technology of billets distribution used by the available planters in the market results in a quite inferior distribution quality compared with manual planting. The lack of spacing uniformity among billets forces to use larger number of buds per lineal meter of furrow. So that after completing the sprouting processes and elimination by natural competition results a population of compatible stems with competitive levels of productivity and longevity.

Ide (2007) considers that success of mechanized planting is dependent on the solution of existing problems such as furrow opening, uniformity of seed distribution and billet recovering, as well as pesticide application. Some of these factors depend on development of implement technology, such as row parallelism, quantity and quality of buds and covering efficiency. The author points out that these factors deserve attention on the part of the researchers to improve effectiveness of sugarcane planting. The author also considers that it is still necessary to discover the ideal system for sugarcane planting, capable to minimize environmental problems and to improve agricultural productivity.

It is possible to get sugarcane vegetative propagation starting from one bud instead of three. This bud is embed in a small billet treated to avoid pests and diseases and having enough energy to hold the development until the root system takes over. The small billet has a more homogeneous geometry to allow for a more precise metering process. That way planting cost is reduced due to the lower volume of seed to be handled by the planter.

As mechanical harvesting grows, labor moves away from the cane fields during the harvesting season. That way the labor cycle is interrupted during the months of April to November, reducing the man power available for sugarcane manual planting. In general the conventional operations involved in sugarcane production involve work conditions and energy demand progressively less compatible with the amount and profile of rural workers available. The accelerated process of cane expansion turns this labor shortage even more critical.

The labor shortage for manual planting and the deficiencies of the available commercial planters turn particularly critical the need for research and development of mechanical processes with equivalent quality to manual planting.

\section{HARVEST}

Sugarcane harvest began in a manual way and it stayed like this for five centuries. Social, economical and technological changes in Australia, in the USA and in Cuba created mechanization proposals in the half of the XX century. In all the cases the proposals just required the recovery of the stalk and the straw was eliminated in the most possible economical way, usually through fire, or it was maintained if necessary, for soil moisture content conservation.

Analyzing the existent crop technologies can be concluded that they are not adequate for present requirements in terms of environmental legislation, efficient recovery of the biomass, sustainable use of the soil and capacity to operate in steeper expansion areas.

The sugarcane harvesting process involves the following six main operations: cut of the stalks at the base and at the top; removal of the stalks from an erect or entangled plantation; parallel ordering of stalks; detrashing; and chopping into 


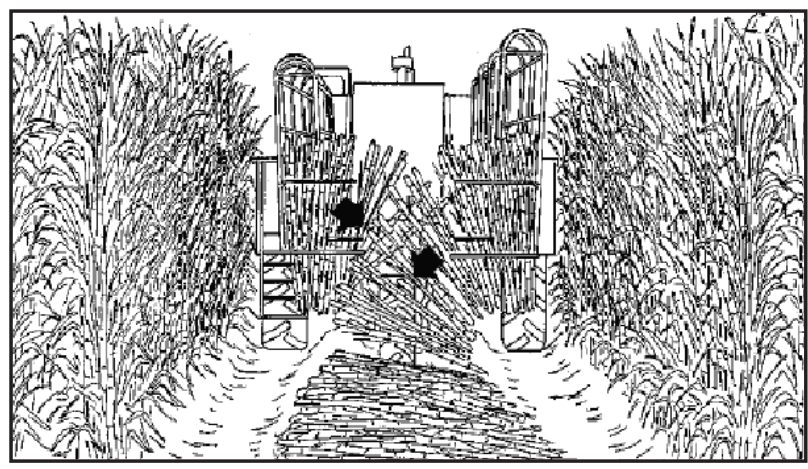

(a)

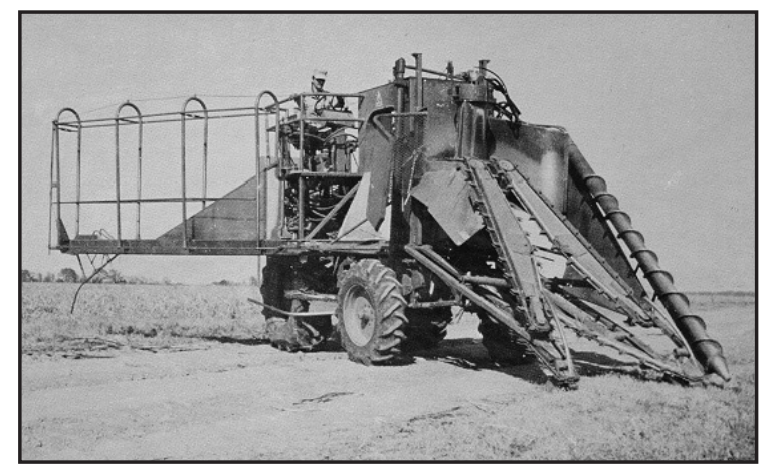

(b)

Source: CTC.

FIGURE 7 Harvesters that use the "soldier" harvesting principle (Louisiana); (a): two rows; (b): one row

billets or whole stalk orderly piling. Today there is no mechanical device able to execute those operations efficiently, either for chopped or for whole stalk cane.

Three harvesting principles, tested along the last 50 years and with characteristics quite differentiated, reached commercial relevance. One is the process called "soldier ", that picks up the whole stalk, erect or little tilted, not entangled, and maintain them ordered parallel; this system executes the cut at the base and tops efficiently with subsequent ordered conduction of the stalk to a pile formed on the soil. Figure 7 illustrates two models of "soldier harvesters" with capacity to cut one or two rows. The "soldier" process presents important restrictions for the present scenario of the sugarcane industry; they are: the impossibility to remove and order stalks of a tangled plantations; the lack of detrashing function, and the intense trampling resulting from the traffic of harvest, loaders and transport vehicles.

A second commercially tested principles it is the process denominated "push-rake ", developed in Hawaii. It is a whole stalk handling process that has been discontinued for several reasons: cane stalks are disorderly removed from the plantation, inexistent or inadequate base and top cut, low load density in transport vehicles, high mineral contamination, use of fire for detrashing and stool destruction during harvesting.
An intermediate harvest principle, among the previous two, is the billet harvesting that appeared almost simultaneously in Cuba and Australia; this system had as initial objective the substitution of scarce labor and the elimination of the whole stalk grab loading operation by introducing bulk handling of billet cane, in the way it is done for grains. The billet or chopped cane harvesting process executes eleven basic operations on the stalks: cut at the tops; rising and alignment; knockdown; base cut; rising of the bottom end; parallel arrangement; chopping; primary ventilation; transport with side elevator; secondary ventilation and dumping into a side wagon.

\section{FINAL CONSIDERATION}

The restrictions of the available technologies for mechanized planting and harvesting of sugarcane are severe, mainly from the stand point of sustainability. They demand research and development of new operational principles as well as exploration and adaptation of scientific and technological solutions available in industrial, military and urban areas. New technologies should be focused specifically on sugarcane instead of just adapting existing mechanization developed for the much larger market of grain crops. The agricultural machinery market is much more attractive and better developed for grain crops, 
even though the potential environmental impacts of mechanization are much higher in the case of sugarcane. The mass handled per hectare at harvesting is over 20 times higher for sugarcane than

\section{REFERENCES}

BRAUNACK M. V.; MC GARRY, D. Traffic control and tillage strategies for harvesting and planting of sugarcane (Saccharum officinarum) in Australia. Soil \& tillage research, v. 89, n. 1, pp. 86-102, 2006.

BRAUNBECK O. A. Novas Tecnologias Mitigadoras no Uso de Água na Produção de Etanol: a Incorporação da Palha para Redução do Estresse Hídrico, XVI Workshop - Uso da Água na Produção de Etanol de Canade-Açúcar, Unicamp/Fapesp, 2008.

CONAB. Companhia Nacional de Abastecimento. Safra Brasileira 2008. Available at: <http://www.conab.gov. br/conabweb/download/safra/3_levantamento2008_ dez2008.pdf>.

CARDOSO, F. P. Estado da Arte do PD - São Paulo: MANAH, 2006. http://www.agrisus.org.br/artigos.asp?.cod=7 CHAMEN, W. C. T.; DOWLER, D.; LEEDE, P. R.; LONGSTAF, D. J. Design, Operation and Performance of a Gantry System: Experience in Arabble Cropping. J. Agric. Eng. Res. v. 59, p. 45-60, 1994.

COX, D. Davco Journey into Precition Farming, Controlled Traffic and Row Spacing Standards, $8^{\circ}$ Seminário de Mecanização e Produção de Cana-de-Açúcar, IDEA, Ribeirão Preto, Março 2006.

DOMINGUES, A. F. I Workshop Brasil - China na área de recursos hídricos, Agência Nacional de Águas - ANA, Brasília, DF, 2006

DOURADO NETO, D. Modelagem em Agricultura, Workshop - Produção Vegetal e Modelagem Agrícola, ESALQ/USP (Piracicaba-SP), julho de 2007. Available at: <http://www.apta.sp.gov.br/cana>. January 2008.

FAO. Food and Agriculture Organization of the United Nations, Production Stat-FAOSTAT. Available at: < http:// faostat.fao.org/site/291/default.aspx>. 2008.

GARSIDE, A. L.; BELL, M. J.; ROBOTHAM, B. G.; MAGAREY, R. C.; STIRLING, G. R. Managing yield decline in sugarcane cropping systems. International Sugar Journal, v. 107, n. 1.273, p. 16-26, 2005.

GHELLER, A. C. A. Técnica para o controle da podridão abacaxi em cana-de-açúcar e modelo para a estimativa de perdas. Piracicaba, 1995. 115p. Dissertação (Mestrado) - Escola Superior de Agricultura "Luiz de Queiroz", Universidade de São Paulo. Disponível na Esalq. it is for grains, while the planted area worldwide is the opposite, about 35 times larger for grains than it is for sugarcane. Breaking this paradigm is a significant challenge.

GRANGE, I.; PRAMMANEE, P.; PRASERTSAK, P. Comparative analysis of different tillage systems used in sugarcane (Thailand). AFBM Journal. v. 2, n. 1, p. 46-50, 2004.

IDE, B. Tecnologia da Produção Agrícola: Gargalos. Workshop Tecnológico sobre Produção Vegetal e Modelagem Agrícola, Painel 4, Programa de Pesquisa em Políticas Públicas, Esalq, Fapesp, 2007.

JANINI, D. A. Análise operacional e econômica do sistema de plantio mecanizado de cana-de-açúcar (Saccharum spp.). Dissertação de mestrado apresentada na Esalq/ USP, Piracicaba. 149p. 2007.

JANINI, D. A.; RIPOLI, T. C.; CEBIN, G. Análise operacional e econômica do sistema de plantio mecanizado de cana-de-açúcar (Saccharum spp.). STAB. Sociedade dos Técnicos Açucareiros e Alcooleiros do Brasil, v. 26, p. 51-57, 2008.

MANOR, G. Automatic Field Machinery, Journal of Terramechanics, v. 32, n. 2, pp. 79-90, 1995.

MARI, G. R.; CHANGYING, J. Influence of Agricultural Machinery Traffic on Soil Compaction Patterns, Root Development, and Plant Growth, Overview. American-Eurasian J. Agric. \& Environ. Sci., v. 3, n. 1, p. 49-62, 2008.

MARI, G. R.; CHANGYING, J.; ZHOU, J.; SHAH BUKHARI, F. Effect of Tillage Machinery Traffic on Soil Properties, Corn Root Development and Plant Growth, Agricultural Engineering International: the CIGR Ejournal. Manuscript PM 06 026. v. VIII, 2006.

MCPHEE, J. E.; BRAUNACK, M. V.; GARSIDE, A. L.; REID, D. J.; HILTON, D. J. Controlled Traffic for Irrigated Double Cropping in a Semi-arid Tropical Environment: Part 1, Machinery Requirements and Modifications, Journal of Agricultural Engineering Research, v. 60, n. 3, p.175-182, 1995.

NASERI, A. A.; JAFARI, S.; ALIMOHAMMADI, M. Soil Compaction Due to Sugarcane (Sacharum Officinarum) Mechanical Harvesting and the Effect of Subsoiling on the Improvement of Soil Physical Properties. Journal of Applied Sciences. v. 7, n. 23, p. 3.639-3.648. 2007.

SILVA, D. Efeito da cobertura nas perdas de solo em um argissolo vermelho-amarelo utilizando simulador de chuva. Eng. Agríc., Jaboticabal, v. 25, n. 2, 2005. 
SMIDERLE, O. J.; GIANLUPPI, D.; GIANLUPPI, V. O Plantio Direto como Sistema de Produção, Embrapa. Available at: <http://www.cpafrr.embrapa.br/index.php/ cpafrr/artigos $>.2005$.

SOUZA, Z. M. de; MELLO PRADO, R. de; STRINI PAIXÃO, A. C.; CESARIN, L .G. Sistemas de colheita e manejo da palhada de cana-de-açúcar. Pesq. Agropec. Bras., Brasília, v. 40, n. 3, p. 271-278, 2005.
TANIMOTO, O. S. Produção de cana-de-açúcar em SPDP. Revista Plantio Direto, edição 107, setembro/outubro de 2008.

YULE, D.; RADFORD, B. Controlled traffic farming. QPI14, case study 9, Queensland Department of Primary Industries, Rockhampton, Austrália, 2003. 